\title{
JUURNAL_RU
}

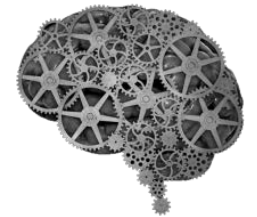

COMPANY GROUP "INTELLEKT"

\author{
Чепеленко К.О.. \\ СГМУ \\ Саратов, Россия
}

doi: 10.18411/lj2016-5-5-14

\section{Авторологические координаты пространства искусства}

Статья посвящена автору художественному в персональном пространстве творческой активности. Тематической локализацией проблемы, ее конкретнопредметной областью выступает автор музыкальный.

Современная научно-исследовательская ситуация характеризуется повышенным интересом к проблеме автора, литературного (В.В. Виноградова, В. Н. Топоров, М. Л. Гаспаров, М. М. Бахтин, Ю. Н. Тынянов, Ю. М. Лотман), музыкального (Л.П.Казанцева, В.И Мартынов, О.А. Губанов). Тема эта на протяжении длительного периода времени сохраняет свою остроту и актуальность.

Современный композитор, как известно - фигура многогранная, «полифонически» организованная; композитор не только пишет музыку, но и возделывает поле ее образно-вербальной интерпретации в целях активной самопрезентации, самопредъявления. По существу, направленность данной работы связана с соотношением музыки и слова в интенциональном пространстве самопрезентации композитора.

Область персонального пространства творческой активности композитора отражает саморефлексивные процессы его интеллектуально-художественной деятельности. Дескрипция этого пространства осуществляется посредством различных стратегий авторского самовыражения, определяемых в терминах 
саможизнеописание, самоинтерпретация, самоаналитика, автооценка, автокомментирование.

Авторологическая концептуальная рамка устанавливает специфику их экспликации. Филологическая теория И.Карпова - теория авторологии отмечает двуединство творческих стратегий: вербальной авторефлексии, с одной стороны, и репрезентации авторского Я в контексте художественного произведения, с другой. В связи с этим, представляется необходимым обращение как словесной практике композитора,так и непосредственно к его музыкальному творчеству.

Очевидна обусловленность музыкальной авторологии спецификой композиторского искусства. Вербальная самопрезентация музыканта осуществляется посредством различных практик и стратегий автобиографического и эпистолярного творчества, теоретической аналитики. Эффективна вербальная самопрезентация посредством авторского слова композитора, произнесенного перед аудиторией, или развернутого в тексте программки концерта, предвосхищающего концертное исполнение музыкальных сочинений.

В стратегиях словесной автопрезентации проявляется высокая степень языковой компетентности композитора. Особенно ярко это качество проявляется в творческой ситуации, когда он сам выступает автором поэтического текста, положенного им же на музыку.

Авторский словесный «антураж» музыкального произведении включает такие субформы как название музыкального произведения, эпиграф (если его автор - композитор), авторские ремарки. Авторская литературная программа более развернутая форма репрезентации художественной интенции композитора (имеется в виду программное произведение), распространенная в современной композиторской практике.

Маркером авторологической интенции выступает автосимволика, отражающая проблематику автостиля (идиостиля). Основа этой стратегии - 
ретроприемы, такие как самоповтор, автоцитата, автомонограмма, автожанр. Все они могут быть относены к универсальным средствам поэтики, имманентной как изобразительному искусству, так и литературе, и музыке.

Особую авторологическую область представляют музыкальные произведения, семантически близкие литературным жанрам автобиографии, воспоминания, исповеди или такому живописному жанру как автопортрет.

Обобщая выше изложенное, необходимо подчеркнуть: авторологический дискурс развертывается по всей вертикали творчества композитора, охватывая поэтику творчества во всех ее проявлениях.

\section{Литература:}

1. Карпов И.П. Авторологическая парадигма (к методологии анализа литературно-художественного произведения) // Науковий вісник Миколаївського державного університету імені В.О. Сухомлинського. Філологічні науки: зб. наук. пр. / за ред. В.Д. Будака, М.I. Майстренко. Миколаїв, 2012. Вип. 4.9. С. 61-68.

2. Чепеленко К.О. Автор пространства искусства: на примере современной отечественной музыки: Монография / К.О. Чепеленко. Саратов: Издательство «Саратовский источник» 2016. 170 с. 